Syntax Fusion : Jurnal Nasional Indonesia

P-ISSN: $x x x x-x x x x$

E-ISSN : $x x x x-x x x x$

Vol. 1, No. 2, Februari 2021

\title{
PERANAN PANCASILA DALAM BERAGAMA DAN BERTEKNOLOGI
}

\author{
Nurul Aulia Dewi, Anissa Nurul Habibah, Nur Azizah Utomo, Ulfah Arump, \\ Azdiva Miftahur Rizkiyah \\ Universitas Islam Negri Syarif Kasim Riau \\ E-mail: nurulauliaa3101@gmail.com, anissanurulhabibah@ gmail.com, \\ nurazizahutomo@ gmail.com, ulfarhump@gmail.com, \\ azdivamiftahur@gmail.com
}

\section{Abstrak}

Pancasila adalah ideologi Negara Indonesia. Yang berarti Pancasila merupakan pedoman bagi warga Negara Indonesia dalam berbangsa dan bernegara. Dirumuskan dan lahir pada 1 Juni 1945 dengan kesepakatan bersama oleh kelompok antar agama, karena itu nilai-nilai Pancasila sama sekali tidak bertolak belakang dengan agama, seperti yang sering diisukan akhir-akhir ini. Peran agama mampu memperkuat dan menyatukan masyarakat dengan nilai-nilai Pancasila. Nilai Pancasila harus selalu ada dalam setiap diri individu, apalagi dengan perkembangan teknologi yang signifikan masuk ke Indonesia dan mengandung berbagai nilai. Tidak semua nilai-nilai yang masuk itu positif, terkadang ada yang masuk dan berbenturan dengan nilai Pancasila. Oleh karena itu sebagai bangsa dengan ideologi Pancasila harus lebih bijak dalam menggunakannya.

Kata Kunci: Pancasila, Teknologi, Agama

\section{Pendahuluan}

Pada tanggal 1 Juni 1945, Soekarno mendapat gilirannya untuk menyampaikan gagasannya tentang dasar Negara Indonesia. Kemudian disahkan tepat sehari setelah kemerdekaan Indonesia pada tanggal 18 Agustus 1945. Oleh karena itu kita sebagai bangsa Negara Indonesia diharuskan untuk menerapkan nilai-nilai di dalamnya. Tapi tidak dapat dipungkiri bahwa tidak seluruh warga Negara ini yang mengerti dan menerapkan dalam kehidupan sehari-hari, termasuk dalam beragama ataupun bersosialisasi secara langsung ataupun tidak langsung (media). "Jangan ada yang merasa paling agamis sendiri. Jangan ada yang merasa paling pancasilais sendiri. Semua yang merasa paling benar dan memaksakan kehendak, itu hal yang biasanya tidak benar.", tegasnya pada sidang tahunan MPR pada Jum'at (14/08/20).

"Bagi seorang Muslim yang iman kuat pasti akan mengedepankan agama di atas segalanya. Yang harus diperhatikan serius oleh Jokowi itu justru yang ingin merubah Pancasila dengan Trisila atau Ekasila tapi merasa paling Pancasilais.", timpa Ketua 
Nurul Aulia Dewi, Anissa Nurul Habibah, Nur Azizah Utomo, Ulfah Arump, Azdiva Miftahur Rizkiyah

Umum PA 212, Slamet Maarif saat wawancara. Dari potongan pidato Presiden Jokowi ataupun pendapat Ketua PA 212, dapat kita simpulkan bahwa keduanya tidak ada yang salah. Karena pada dasarnya nilai Pancasila tidak boleh bertabrakan dengan nilai-nilai Agama. Jangan sampai kita menghilangkan salah satunya dan berpihak pada salah satunya dalam menjalankan kehidupan. Nilai-nilai yang terkand ung pada keduanya saling berketergantungan. Namun masih ada banyak orang yang mempermasalahkannya. Begitu juga berita yang sering muncul dalam media akhir-akhir ini, tidak banyak yang menyebarkan berita tidak nyata atau yang sering disebut dengan hoax.

Sebagai masyarakat awam tentu kita tidak dapat mengetahui berita yang benar dan berita yang salah, yang terkadang media juga memberikan bukti berupa hanya sepotong video ataupun foto yang belum tentu ada. Sehingga menjadikan masyarakat menerkanerka yang mana yang benar. Apalagi dengan kemajuan teknologi khususnya informasi ini menjadikan kabar yang belum tentu benar ini cepat diterima oleh mas yarakat melalui jaringan sosial. Ditambah lagi dengan terjadinya pandemi covid-19 ini tercatat peningkatan jumlah kasus penyebaran berita hoax ini dibandingkan tahun 2019. Karena dengan tersebarnya berita hoax ini tidak jarang tersebarnya juga ujaran kebencian atau yang dikenal dengan hate speech. Dan banyak pengaruh buruk lainnya dari berita palsu ini. Oleh sebab itu kami segenap penulis tertarik membuat tulisan jurnal tentang "Peranan Pancasila dalam beragama dan berteknologi".

\section{Metode Penelitian}

Dalam studi ini kami menganalisis dan meneliti beberapa artikel untuk mendapatkan argumen-argumen pada isi jurnal ini. Dan menurut hasil pandang kami, bahwa kemajuan pesat teknologi dapat berdampak buruk terhadap norma-norma agama khususnya Islam dan nilai-nilai Pancasila yang mulai hilang di tengah-tengah masyarakat Indonesia saat ini. Karena banyak teknologi khususnya via media online menyebarkan atau menyediakan konten-konten yang tidak mencerminkan perilaku bangsa Indonesia, sedangkan ideologi bangsa Indonesia sendiri adalah Pancasila. Dengan adanya ideology inilah potensi kemajuan bangsa dinilai, tetapi ternyata selain menjadi ideologi Pancasila dapat menjadi ancaman sendiri bagi bangsa Indonesia. Karena dengan Pancasila itu pula bangsa Indonesia bisa hancur sebab tidak menerapkan nilai-nilainya dalam kehidupan sehari-hari.

Sifat-sifat buruk yang terjadi sekarang efek kemajuan teknologi ini menyebar luas dalam dunis maya hingga dunia nyata, berbagai ujaran kebencian. Dengan menghina satu sama lain melalui beberapa indikator seperti ras, agama, budaya dan lainnya. Harusnya itu semua bisa menjadi kebanggaan setiap bangsa Indonesia, tetapi yang terjadi sekarang adalah sebaliknya.

Tidak sedikit pada waktu sekarang ini sifat toleransi beragama di Indonesia yang mulai hilang. Padahal sudah sangat jelas dalam Pasal 28I ayat (1) bahwa hak untuk beragama merupakan hak asasi manusia. Juga diterangkan dalam Al-Qur'an Surah AlKafirun:6 berbunyi "Untukmu agamamu, untukku agamaku". Bahkan juga ada yang mempermasalahkan nilai Islam dan nilai Pancasila, yang sebenaranya kedua nilai itu 
saling berkaitan dan tidak dapat dipisahkan. Kedua nilai inilah yang harus diaplikasikan dalam kehidupan sehari-hari dan juga dalam memanfaatkan kemajuan teknologi. Kedua Nilai ini akan menjadi barometer ukur kemajuan bagi bangsa Indonesia sendiri. Karena dengan nilai-nilai agama dan Pancasila bangsa Indonesia tetap memiliki ciri khasnya dan sebagai bangsa yang santun.

\section{Hasil dan Pembahasan}

\section{A. Keterkaitan Antara Nilai Pancasila, Keaganaan, dan Teknologi}

Manusia adalah makhluk yang cerdas. Mereka memiliki akal budi, rasa dan daya cipta yang digunakan untuk memahami eksistensinya, dari mana sesungguhnya ia berasal, dimana berada dan akan kemana perginya. Pertanyaan-pertanyaan selalu muncul, akan tetapi pertanyaan itu belum pernah berhasil dijawab secara tuntas. Manusia tetap saja diliputi ketidaktahuan.

Berdasarkan rasa dan daya cipta yang dimilikinya manusia mengembangkan ilmu pengetahuan dan teknologi (IPTEK). Namun, perkembangan teknologi yang luar biasa menyebabkan manusia menjadi lupa diri. Manusia menjadi individual, egoistik dan eksploitatif, baik terhadap diri sendiri, sesama, masyarakat, alam lingkungan, bahkan terhadap Tuhan Sang Pencipta. Karena itulah filsafat ilmu pengetahuan dihadirkan ditengah-tengah keaneka ragaman Ilmu Teknologi. untuk meluruskan jalan dan menepatkan fungsinya bagi hidup dan kehidupan manusia di dunia ini.

Kemajuan sains dan teknologi telah memberikan kemudahan-kemudahan dan kesejahteraan bagi kehidupan manusia sekaligus merupakan sarana bagi kesempurnaan manusia sebagai umat manusia. Tuhan telah mengaruniakan anugerah kenikmatan kepada manusia yang bersifat saling melengkapi yaitu anugerah beragama dan kenikmatan sains teknologi. Agama dan Ilmu pengetahuan-teknologi merupakan dua sisi yang tidak dapat dipisahkan satu sama lain. Ilmu adalah sumber teknologi yang mampu memberikan kemungkinan munculnya berbagai penemuan rekayasa dan ide-ide. Adapun teknologi adalah terapan atau aplikasi dari ilmu yang dapat ditunjukkan dalam hasil nyata yang lebih canggih dan dapat mendorong manusia untuk berkembang lebih maju lagi. Namun, terlepas dari semua itu, perkembangan teknologi tidak boleh melepaskan diri dari nilainilai agama.

Sebagaimana yang diungkapkan oleh Fisikawan besar, Albert Einstin yang menyatakan: "Agama tanpa ilmu akan pincang, sedangkan ilmu tanpa agama akan Buta”. Sebagai umat dari Agama Islam kita harus menyadari bahwa dasar-dasar filosofis untuk mengembangkan ilmu dan teknologi itu bisa dipelajari dan dikaji dalam Al-quran sebab kitab suci ini banyak membahas keterangan-keterangan mengenai ilmu pengetahuan dan teknologi. Sebagai contohnya firman Allah SWT dalam surat Al-Anbiya ayat 80 yang artinya "Telah kami ajarkan kepada Daud membuat baju besi untuk kamu guna memelihara diri dalam peperanganmu. ” Dari keterangan tersebut telah jelas bahwa manusia dituntut untuk berbuat sesuatu dengan sarana teknologi. akibatnya tidak mengherankan jika abad ke-7 M telah banyak tercipta dari pemikiran Islam yang tangguh 
Nurul Aulia Dewi, Anissa Nurul Habibah, Nur Azizah Utomo, Ulfah Arump, Azdiva Miftahur Rizkiyah

produktif dan inovatif dalam pengembangan ilmu pengetahuan dan teknologi. Estafet dan keunggulan umat Islam dalam bidang ilmu pengetahuan sudah dimulai pada abad itu. Tetapi sangat disayangkan bahwa kemajuan-kemajuan itu tidak sempat dilanjutkan dengan sebaik-baiknya sehingga tanpa sadar umat Islam akhirnya melepaskan keunggulannya. Lalu bangsa Barat dengan mudah mengambil dan memindahkan ilmu dan teknologi yang dimiliki dunia Islam dan dengan mudah pula mereka berbuat licik yaitu membelenggu para pemikir Islam sehingga sampai saat ini bangsa Baratlah yang menjadi pelopor dan pengendali ilmu pengetahuan dan teknologi.

Negara Indonesia merupakan banyak yang menjadikan ideologi pancasila sebagai dasar dalam kehidupan berbangsa dan bernegara. Ideologi pancasila yang lahir sejak pembentukan negara Indonesia dan diterapkan mulai kemerdekaan yang diraih oleh salah satu negara berpenduduk terbesar di Indonesia ini tentu memiliki hubungan dengan banyak hal salah satunya terkait Agama. Pancasila sebagai falsafah bangsa yang memberikan landasan konsep filosofis dan historis untuk menjalankan sistem hidup dan kehidupan kebangsaan di bumi tanah air Indonesia dan mampu menjadikan Pancasila sebagai karakter kepribadian insan manusia Nusantara sehingga akan menjadikan manusia yang adil dan beradab, menusia yang bersatu, manusia yang siap untuk memimpin dan dipimpin dengan konsep hikmat dan kebijaksanaan dalam upaya menciptakan keadilan sosial bagi seluruh rakyat Indonesia. Prinsip atau asas Ketuhanan Yang Maha Esa merupakan sila utama dalam struktural piramida Pancasila. Pemahaman yang benar akan nilai-nilai, sifat dan karakter Ketuhanan Yang Maha Esa akan memberikan moralitas spiritual ilmiah sehingga mampu memberikan konsepsi dalam membangun peradaban bangsa yang akan selalu terjadi sepanjang masa.

Tiga dari empat indikator moderasi beragama yaitu, komitmen, kebangsaan, toleransi, anti kekerasan, mempertegas keharusan Negara untuk menjamin egalitarianism hak semua warga Negara serta hadir sebagai fasilitator untuk menjembatani perbedaan yang ada. Komitmen kebangsaan berarti pandangan, sikap, dan praktek beragama yang bersinergi dengan komitmen dan loyalitas pada empat consensus dasar (NKRI, Pancasila, UUD 1945, dan Bhineka Tunggal Ika). Afirmasi prinsip egalitarianism dan dialog merupakan salah satu bentuk komitmen dan loyalitas kepada keempat consensus dasar bangsa tersebut. Sebagai indicator moderasi, toleransi dimaknai atau diartikan sebagai sikap memberi ruang dan tidak mengganggu hak orang lain untuk berkeyakinan dan mengekspresikan keyakinannya, meskipun hal tersebut berbeda dengan apa yang kita yakini. Toleransi yang dimaksud mencakup relasi antar danitra agama. Toleransi antaragama mencakup kesediaan, dialog, interaksi, dan kerjasama.

Untuk pembangunan bangsa dengan menciptakan karakter kebangsaan melalui nilai luhur Pancasila, Implementasi membangun peradaban dengan melakukan karyakarya konkrit dalam bidang budaya, sosial dan ilmiah. Perpaduan spiritual Pancasila dan teknologi akan menghasilkan peradaban bangsa bahkan dunia. Indonesia akan menjadi bangsa besar dan pelita dunia manakala seluruh manusia Nusantara yang terikat oleh perjanjian luhur satu nusa, satu bangsa, dan satu bahasa kembali menjadikan Ketuhanan 
Yang Maha Esa sebagai karakter bangsa. Semua hidup ini terikat oleh hukum waktu, semua dipergilirkan sesuai jamannya.

Dalam ideologi pancasila selalu mencoba untuk tetap menjaga hubungan yang baik antara agama dan negara serta tidak akan melakukan upaya memisahkan keduanya. Dengan dasar tersebut yang tertuang dalam sila sila pancasila dan penjelasan UUD 1945 ada beberapa bentuk hubungan antara agama dan negara berdasarkan ideologi Pancasila diantaranya seperti:

- Hubungan negara dan agama menurut fungsi Pancasila sebagai ideologi negara menjadikan setiap warga negara dengan Ideologi Pancasila memiliki hak asasi manusia untuk dapat memeluk agama dan menjalankan ibadahnya sesuai dengan ajaran agama yang dikehendakinya.

- Negara harus dapat memberikan toleransi setiap Agama menjalankan ibadahnya tanpa terkecuali sehingga tidak ada tempat untuk berkembanganya pertentangan antara agama, konflik agama, hingga paksaan untuk bertakwa pada agama tertentu karena dalam idelogi pancasila dijelaskan bahwa agama tidak dipeluk atas dasar paksaan.

- Segala bentuk aspek penyelengaraan negara harus berdasarkan atas nilai nilai dalam ketuhanan yang maha esa. Setiap aturan yang dibuat harus memperhatikan sikap toleransi antara beragama.

Itulah beberapa penjelasan mengenai hubungan negara dan agama menurut ideologi Pancasila yang diterapkan sebagai dasar dari negara Indonesia. Penjelasan hubungan yang diuraikan tersebut akan memapu memahami lebih jauh mengenai id eologi Pancasila yang berkembang di Indonesia.

Di jelaskan dalam surah Ar-Rahman ayat 33 bahwa manusia dianjurkan untuk melintasi bumi dan langit, dan melakukan itu manusia harus memiliki kekuatan: baik kekuatan keilmuan (IPTEK) maupun kekuatan keimanan (IMTAQ) sungguh jelas maksud dari ayat tersebut bahwa kedua komponen ini tidak dapat dipisahkan karena saling berkaitan demi mencapai kesejahteraan manusia dunia dan akhirat.

\section{B. Pengaruh Besar Nilai Pancasila Terhadap Perkembangan Teknologi}

Selain Pancasila dan agama yang memiliki perselisihan, dalam bidang perteknologian juga terdapat problematikanya sendiri. Teknologi dapat meningkatkan kualitas dan jangkauan bila digunakan dengan bijak dan benar, apalagi disamping penggunaannya masyarakat Indonesia memasukkan nilai-nilai Pancasila di dalamnya. Karena di zaman ini perkembangan teknologi merupakan dasar untuk mengembangkan kehid upan berbangsa dan Negara. Karena seberapa besar ilmu pengetahuan dan teknologi yang dikuasai pada suatu Negara menjadi salah satu tolak ukur kemajuan suatu Negara tersebut. Dan Indonesia merupakan Negara yang terkena globalisasi, oleh karena itu bangsa Indonesia mau tidak mau harus terlibat dalam maju mundurnya teknologi ini. Pancasila bukan hanya sebagai dasar nilai ilmu pengetahuan dan teknologi saja, tetapi Pancasila sudah menjadi paradigma ilmu dan teknologi yang berkembang di Indonesia. Di era ini Indonesia harus terus mempertahankan yang sudah menjadi ideologinya yaitu 
Nurul Aulia Dewi, Anissa Nurul Habibah, Nur Azizah Utomo, Ulfah Arump, Azdiva Miftahur Rizkiyah

Pancasila untuk menjaga eksistensi kepribadian bangsa dengan menjadikannya acuan untuk menghadapi tantangan global dunia.

Banyaknya nilai-nilai negatif yang masuk ke Indonesia dan bertentangan dengan nilai-nilai Pancasila dan merusak moral bangsa, maka diperlukan tuntutan moral bagipara ilmuwan dalam pengembangan teknologi di Indonesia. Dan juga sangat diperlukan orientasi yang jelas untuk menyaring ataupun menangkal pengaruh dari nilai-nilai global yang tidak sesuai dengan Pancasila. Bukan nilai baru yang harus diaplikasikan dalam hid up ini, tapi justru nilai lokal yang bermoral yang ada dalam Pancasila yang harus kita perjuangkan dan lestarikan dalam kehid upan sehari-hari. Apalagi generasi muda penerus bangsa harus lebih berhati-hati dalam memanfaatkan teknologi ini karena Negara Indonesia masa yang akan datang akan bergantung pada pemudanya di masa kini. Jika kita dapat memfilter berbagai hal yang muncul akibat dari dampak globalisasi ini dengan baik, tentu hasilnya akan positif. Karena dapat menambah wawasan dan mempererat hubungan antar bangsa dan Negara di dunia. Hasilnya akan negatif, jika kita tidak dapat memfilternya dengan baik. Contohnya, budaya asing yang telah mempengaruhi perilaku dan pola pikir masyarakat Indonesia.

Kelalaian kita terhadap penggunaan teknologi ini terkadang membuat kita lupa untuk berinteraksi sosial, yang menjadikan kita memiliki sifat individualism yang tinggi. Padahal kodrat kita sebagai manusia ialah mkhluk sosial, yang saling membutuhkan satu sama lain. Sehingga mulai hilang makna dari sila ketiga "Persatuan Indonesia". Nilai Pancasila ini akan berpengaruh positif terhadap memajukan Negara Indonesia, apabila nilai-nilai Pancasila diamalkan dalam kehidupan. Namun sebaliknya kemungkinan akan terjadi jika nilai-nilai Pancasila tidak diterapkan karena tergeser pola pikir dari Barat.

Salah satu usaha untuk mencegah hilangnya nilai-nilai Pancasila adalah dengan melakukan sosialisasi atau penyuluhan nilai-nilai Pancasila kepada orang-orang atau daerah pelosok yang minim akan pendidikan. Agar selalu diingat dan ditanamkan dalam jiwanya bahwa nilai-nilai moral yang ada dalam Pancasila sangatlah penting bagi kehidupan. Dan bagi kita generasi muda hendaknya berd iri sebagai pengingat bagi orangorang yang telah terbawa arus globalisasi dan melanggar nilai-nilai Pancasila. Sila pertama yang bermakna bahwa kita harus saling toleransi dan menghargai dengan agamaagama yang berbeda-beda. Dalam sila kedua dijelaskan bahwa kita sebagai manusia harus menjunjung tinggi nilai kemanusiaan. Dan sila ketiga yang berbunyi "Persatuan Indonesia", menunjukkan bahwa kita harus bersama dan bersatu untuk lebih mencintai tanah air Indonesia dan bangga menjadi bangsa Indonesia. Sila keempat mengharuskan kita sebagai bangsa yang satu untuk selalu bermusyawarah sebelum mencapai mufakat. Dan pada sila kelima yaitu sila terakhir dari Pancasila sendiri mengharuskan kita untuk menjunjung tinggi keadilan bagi setiap bangsa mau itu dalam bidang ekonomi, sosial, politik, dan terutama di bidang hukum. Dalam memanfaatkan dan menyebarkan informasi teknologi dan komunikasi seharusnya didalamnya ada nilai-nilai tersebut. Agar masyarakat Indonesia pun tidak akan lupa dan ikut mengaplikasikan Pancasila dalm kehidupannya. Kemajuan kehidupan ekonomi yang terlalu menekankan pada upaya pemenuhan berbagai keinginan material, telah menyebabkan sebagian warga masyarakat 
menjadi kaya dalam materi, namun miskin dalam segi rohani. contoh permasalahan perkembangan Iptek di Indonesia ini salah satu bullying berunsur di media sosial, pengguna media sosial tidak mengenal umur dan gender membuat pengguna media sosial bersemena-mena dengan mudah mempercayai hal tersebut, Selain contoh bullying juga ada penipuan online, di mana penipu-penipu yang berkeliaran di online mempunyai sikap yang individualis karena tidak memikirkan orang lain yang mereka tipu dan tidak berkemanusiaan, juga penyebaran pornografi di banyak platform itu juga termasuk permasalahan perkembangan ilmu teknologi. Itulah mengapa teknologi ini bukan hanya sekedar memudahkan kehidupan semata tapi juga datang pengaruh-pengaruh diluar nilainilai Pancasila beriringan dengan itu semua.

Kita harus pintar dan bijak untuk memilih konten yang akan kita lihat dan yang mana yang harus dipraktekkan dalam kehidupan. Padahal tidak ada keuntungan untuk diri sendiri jika kita mengikuti gaya hidup di Barat yang ada hanya akan membahayakan moral kita dan kepribadian kita sebagai bangsa Indonesia. Rasa kecintaan terhadap tanah air pun akan berkurang sehingga nilai nasionalisme hilang, sosialisai terhadap mas yarakat pun akan ikut berkurang. Jangan sampai dengan kemajuan perkembangan teknologi ikut menaikkan angka kriminal yang terjadi. Moral yang rusak tidak hanya berdampak pada kehidupan nyata saja, dalam kehidupan bermedia sosial pun banyak dampaknya.

Berita yang begitu cepat dapat terakses oleh masyarakat memudahkan akun atau media penyebar berita bohong atau hoax ini merajalela. Karena masyarakat dengan mudahnya terpengaruh dalam berita yang ia lihat padahal belum ada kejelasan masalahnya. Sehingga dari berita yang belum tahu kejelasannya ini meyebabkan masyarakat tertipu dan meyebabkan ujaran kebencia di dalam sosial media atau yang disebut dengan hate speech. Berita yang seperti ini sangat sulit dibedakan dengan berita yang asli. Oleh karena itu, masyarakat hanya mendeskripsikannya sesuai dengan apa yang ia peroleh tanpa mau tahu mencari informasi dari sumber yang lain. Ini juga sebab dari adanya kerusakan moral akibat pesatnya teknologi, yang selalu mengkritik dan menghakimi tanpa tahu yang sebenarnya. Sama halnya dalam media yang suka meprovokasikan antar kelompok misalnya. Dampak negatif perkembangan teknologi menjadikan kabar atau berita yang masuk sulit disaring, yang belum terverifikasipun masuk dengan mudahnya dan langsung sampai pada masyarkat dalam hitungan detik. Para penyebar sering beralasan dengan mengatasnamakan kebebasan berpendapat yang ia punya dalam bermedia, inilah contoh orang yang tidak faham dari Pancasila tersebut.

Lagi dan lagi anak muda penerus bangsa lah yang harus menjadi andil utama dalam menanam dan menumbuhkan kembali nilai- nilai Pancasila. Selain berpendidikan kita juga harus memilikiperilaku yang baik yang patut dicontoh oleh generasi setelah kita nanti. Karena banyaknya pengaduan tentang berita hoax ini, MenKomInfo (Menteri Komunikasi dan Informasi) bekerjasama dengan aparat kepolisian untuk menyisir dan memblokir akun atau media tersebut. Dalam masalah penyalahgunaan dunia maya ini masuk dalam pelanggaran UU ITE maka dari itu aparat bertindak. Selain aparat ataupun kementerian kita sebagai bangsa Indonesia juga harus pintar memilah berita ataupun kabar yang masuk ke dalam beranda yang mana yang benar dan mana yang salah. Dan 
Nurul Aulia Dewi, Anissa Nurul Habibah, Nur Azizah Utomo, Ulfah Arump, Azdiva Miftahur Rizkiyah

jika ingin mengetahuinya lebih lanjut kita harus mencari informasi tersebut lebih jauh lagi dan menuntaskannya agar kita tidak sampai salah berkomentar. Jika kita sibuk dengan menghakimi dan tanpa tahu kebenarannya maka terjadi perselisihan dalam dunia maya tersebut dan menambahkan ujaran kebencian lagi dan tiada habisnya. Maka dari itu sudah menjadi keharusan bagi setiap kepala untuk menerapkan nilai-nilai Pancasila dalam kehidupannya, supaya dapat memahami bersosial yang baik dalam dunia nyata ataupun maya. Dan agar moral yang kita miliki dan kita jaga selama ini tidak rusak dan hilang begitu saja. Menjadi bangsa Negara Indonesia harusnya memiliki kebanggaan tersendiri bagi setiap individu, selain karena alamnya yang indah, Indonesia mengajarkan kita dengan nilai-niali yang terkandung dalam Pancasila yang tidak melepaskan kewajiban kita beragama. Jika budaya Barat yang terus kita aplikasikan dalam kehidupan, maka beriringan akan hilangnya Pancasila dalam jiwa kita.

Dampak positif yang dapat dirasakan melalui majunya iptek dalam bidang keamanan dan pertahanan negara:

1. Meningkatnya keandalan teknologi persenjataan dengan software dan rekayasa hardware.

2. Cepatnya teknologi informasi dalam menyampaikan informasi sehingga cepatnya dalam pengambilan suatu keputusan.

3. Mencegah terjadinya penyerangan-penyerangan dari pihak yang ingin memecah kesatuan Negara Indonesia.

4. Mencegah terjadi pecah belah yang terjadi akibat perbedaan dalam kehiduan bernegara dan berbangsa melalui media informasi, seperti internet.

Dampak negatif yang dapat dirasakan melalui majunya iptek dalam bidang

keamanan dan pertahanan negara:

1. Terjadinya penyalahgunaan satelit oleh para teroris baik dalam maupun luar negeri, seperti melacak kondisi tempat untuk mereka melakukan kejahatan.

2. Terjadinya perang informasi dengan memanfaatkan perkembangan dari teknologi informasi dimana pengunaannya dapat dipakai bersama.

3. Melalui internet, teroris dapat berkomunikasi dengan teroris lainnya dan mencari pengikutnya melalui media internet.

Nilai-nilai dalam Pancasila juga menjadi suatu sumber motivasi agar berkembangnya Ilmu Pengetahuan dan Teknologi (IPTEK) nasional dan dapat mencerdaskan bangsa yang dimana mempunyai nilai-nilai Pancasila yang tinggi serta dapat menegakkan kemerdekaan secara utuh dan daulat. Juga martabat nasional dapat terwujud sebagai negara Indonesia yang merdeka, yakni Negara Kesatuan Republik Indonesia. Oleh karena itu filosofis-ideologis dan konstitusional NKRI dinamakan (predikat) sebagai suatu sistem kenegaraan Pancasila yang canggih dan modern.

Jika tabel memiliki lebar melebihi lebar kolom pengetikan, maka dapat ditampilkan di tengah-tengah bidang pengetikan.

\section{Penutup}


Dalam hidup ini tidak telepas dari Ilmu Pengetahuan dan teknologi, Iptek dapat dispesifikasikan sebagai ilmu/berilmu sedangkan Imtaq sendiri sebagai Iman/Beriman, keseimbangan yang maksud disini adalah contohnya dalam mengoperasikan teknologi yang ada untuk mengolah suatu Ilmu maka disinilah Iptek berperan adapun peran Imtaq dalam hal ini sebagai suatu pengaturan jiwa sehingga melahirkan moralitas yang etis, contohnya dalam mengolah ilmu itu sendiri dengan menggunakan teknologi sesuai kebutuhan pengolahan tentunya membutuhkan kesabaran atau kebesaran jiwa dalam menghadapi segala tantangan, kendala-kendala, dan hambatan dalam menyelesaikannya.

kita mengambil contoh yang lebih spesifik lagi. sebagai mahasiswa tentunya yang menjadi tantangan dalam dunia mahasiswa adalah penyelesaian tugas baik tugas awal, pertengahan, dan akhir. Selama mengikuti perkuliahan sesungguhnya membutuhkan kesabaran yang kuat, dan kesabaran ini dapat kita sadari ketika mindset kita tentang hubungan kita kepada-Nya, bagaimana kita berfikir positif terhadap segala ujian yang kita dapatkan baik itu ujian berupa musibah maupun ujian berupa kesenangan.

Masih terkait dengan kesabaran kita menghadapi tantangan dalam dunia mahasis wa tentu peran kita sebagai agen of change. sangat berperan dalamkeilmuan lebih peka terhadap realitas kehidupan, dan yang menjadi pondasinya adalah keimanan atau Imtaq itu send iri dengan kita memiliki jiwa yang taat dan yakin keberadaan sang pencipta, niscaya kita akan selalu menjadi magnet keberkahan dan hidayah.

\section{Bibliografi}

Darmodihardjo, Dardji. 1978. Orientasi Singkat Pancasila, Jakarta: PT. Gita Karya. Darmodihardjo, Dardji. 1991. Santiaji Pancasila. Edisi Revisi, Surabaya: Usaha Nasional.

Dit Belmawa, Ditjen Dikti, 2013. Bahan kuliah mata kuliah Pancasila, Jakarta: Dit Belmawa, Ditjen Dikti.

Dit. Belmawa. 2016. Pendidikan Pancasila Untuk Perguruan Tinggi. Cetakan 1. Jakarta: Ditjen Pendidikan Tinggi Kemenristekdikti.

Fauzi, Achmad. 1983. Pancasila Ditinjau Dari Segi Yuridis Konstitusional dan Segi Filosofis, Malang, Lembaga Penerbitan Universitas Brawijaya.

Kaelan, 2000. Pendidikan Pancasila. Yogyakarta: Paradigma.

Kristiono, Natal. Penguatan Pancasila di kalangan mahasiswa Universitas Negeri

Semarang. Jurnal Harmony Vol. 2 No. 2, hal 193-204.

Moleong, J (2004) MetodologiPenelitian Kualitatif. PT. Remaja Rosdakarya. Bandung. Nurdin, Encep Syarief. 2012. Pancasila Dalam Kajian Sejarah Bangsa Indonesia, e-Materi Pendidikan Pancasila. Yogyakarta: Dikti dan UGM.

Sekretariat Jenderal MPR-RI. 2013. Pimpinan MPR dan Tim Kerja Sosialisasi MPR Periode 2009--2014. Empat Pilar Kehidupan Berbangsa dan Bernegara. Jakarta:. 
Nurul Aulia Dewi, Anissa Nurul Habibah, Nur Azizah Utomo, Ulfah Arump, Azdiva Miftahur Rizkiyah

Safrul, Lande, Alfi dan Mahpudz, Asep. Impleme-ntasi Nilai-nilai Pancasila di SMA Negeri 4 Palu.

Siswanto, Joko. 2015. Pancasila (Refleksi Komperehensif Hal-Ikhwal Pancasila). Yogyakarta: Ladang Kata.

Soekarno, 1984. Pancasila Sebagai Dasar Negara, Jakarta: Inti Idayu Press dan Yayasan Pendidikan Soekarno.

Sugiono (2010). Metode Penelitian Pendidikan Kualitatif. Bandung: Alfabetha.

Suwarno, 1993. Pancasila Budaya Bangsa Indonesia, Yogyakarta: Yayasan Kanisius.

Suhadi. 2001. Pendidikan Pancasila Untuk Perguruan Tinggi. Yogyakarta: Yayasan Pembinaan Fakultas Filsafat UGM.

Tim Penyusun Pusat MKU, 2016. Modul Pancasila. Malang: Universitas Brawijaya. Undang-Undang No 12 tahun 2012 tentang Pendidikan Tinggi. Jakarta: Kemenkumham Republik Indonesia.

Yacob, Tengku. 1993. Manusia, Ilmu dan Teknologi, Yogyakarta: PT. Tiara Wacana. 